\title{
CircFlNA Acts as a Sponge of miR-646 to Facilitate the Proliferation, Metastasis, Glycolysis, and Apoptosis Inhibition of Gastric Cancer by Targeting PFKFB2 [Corrigendum]
}

Qu J, Yang J, Chen M, Wei R, Tian J. Cancer Manag Res. 2020;12:8093-8103.

On page 8094, Materials and Methods, Samples Collection section, the IRB number reported was incor- rect. The correct number is NKYY_YXKT_IRB_20 20_067_01.

The authors apologize for this error.
Cancer Management and Research is an international, peer-reviewed open access journal focusing on cancer research and the optimal use of preventative and integrated treatment interventions to achieve improved outcomes, enhanced survival and quality of life for the cancer patient.
The manuscript management system is completely online and includes a very quick and fair peer-review system, which is all easy to use. Visit http://www.dovepress.com/testimonials.php to read real quotes from published authors. 